\title{
Schooling Effect in Economic Growth: Benchmarking Turkey vs High Income Countries
}

\author{
Metin Gurler ${ }^{1 *}$ and Ozlem Ozsoy ${ }^{2}$ \\ ${ }^{1}$ Assistant Professor, URAK, Istanbul, Turkey \\ ${ }^{2}$ Nurse Manager, EKOL KBB Hospital, Izmir, Turkey \\ *Corresponding Author: Metin Gürler, Assistant Professor, URAK, Istanbul, \\ Turkey.
}

DOI: $10.31080 /$ ASNH.2020.05.0812
Received: November 19, 2020

Published: January 16, 2021

(C) All rights are reserved by Metin Gurler and

Ozlem Ozsoy.

\begin{abstract}
In modern economic growth theory, human capital is not only an important source in the growth of economy but also has got a significant effect on productivity. According to the analysis of the results based on random effects estimation with panel and crosssection data in the study, mean years of schooling is found as a determinant of the economic growth via health improvement achieving a productive labour force in High Income Countries. Data for mean years of schooling was obtained from United Nations Development Programme (UNDP) Human Development Reports and Barro-Lee Educational Attainment Dataset whereas for income per capita from the World Bank for the 12 periods in 1995-2014 for 37 High Income Countries and Turkey. Since mean years of schooling in Turkey has been found less than the High-Income Countries' values, she should increase mean schooling years to reach a healthy well-being level to get a productivity progress causing a rapid economic growth as advanced countries.

In the study we analysed Turkey vs 37 High Income Countries. Turkey who is also an emerging economy has a risk to rise to an upper income level as some other middle income countries have. The case is called in literature as "Middle Income Trap". So benchmarking Turkey (the 17th greatest economy in the world) vs High Income Countries is important to show guidelines avoiding the Middle Income Trap.

Granger causality test is also applied to test the direction of causality between mean years of schooling (MYS) with national income per capita (IPC) and vice versa, and it is seen that mean years of schooling (MYS) Granger causes economic (income per capita) growth (IPC) for panel data. For cross-section data analysis there is no proved correlation between mean years of schooling (MYS) and economic growth (IPC) and vice versa.

Keywords: Mean Years of Schooling; Human Capital; Economic Growth
\end{abstract}

JEL Classification: I25, 047, C31, C33, J24.

\section{Introduction}

Since the capital is scarce in developing countries labour is the first and main determinant of in economic development in low and middle income countries. At the first stages of industrialization labour force is the key determinant of growth at the initial level of development for emerging countries such as Turkey. An improve- ment in health status of labour force increases the productivity resulted with an economic growth and enhancing income per capita in a country.

Increasing schooling years let the development of preventive and therapeutic methods against diseases which will increase not only the life expectancy of the citizens at birth but the productivity of labour force in the country as well. Healthy labour force 
will cause national income and income per capita getting upward slope. Income growth will also affect education expenditures positively. This positive feedback will last with the income increase.

The relationship between mean years of schooling and economic growth of Turkey comparing with 37 High Income Countries was tested within the study empirically. A literature review of the subject summarizing some important previous studies theoretically and empirically was also conducted at the beginning. In the following chapter the effect of mean years of schooling on economic growth was investigated by Cross Section and Panel Data Models using data gathered from the World Bank, United Nations Development Programme and Barro-Lee [1].

In this study, totally 37 High Income Countries those might be taken as an example of economic development success along with Turkey have been investigated by Cross Section and Panel Data Analysis. Turkey, the $18^{\text {th }}$ largest economy ${ }^{1}$ in the world has not been found taking place at a very successful ranking in the analysis. The relationships of mean years of schooling (MYS) with national income per capita (IPC) for 37 High Income Countries have been tested with both Cross-sectional Data Method for 2014 year and Panel Data Method for 12 periods starting from 1995 ending $2014^{2}$. By giving priority to schooling of the population productivity should be increased via getting healthy and feeling well-being.

Granger causality test is also applied to test the direction of causality between mean years of schooling (MYS) with national income per capita (IPC) and vice versa.

\section{Literature Survey}

The Human Development Report [2], which is regularly published annually by the United Nations, seems to have put people at the centre of development. In the report, countries were divided into four groups as the Very High Human Development (49 countries according to the 2015 report), the High Human Development (56 countries according to the 2015 report), the Medium Human Development (38 countries according to the 2015 report) and the
Low Human Development (44 countries according to the 2015 report). In the study the countries are classified with the help of an index called as the Human Development Index consisting of 3 subindices. The Education Sub-index which tells knowledge dimension of the sub-indices is defined as a combination of mean years of schooling and expected years of schooling indicators of the sub-index. The Life Expectancy Index that is another sub-index is defined as a dimension of long and healthy life where the life expectancy at birth is an indicator of the sub-index ${ }^{3}$.

At OECD Copenhagen Symposium about Measuring the Effects of Education on Health and Civic Engagement Feinstein et al. [3] in their study expressed that more years of schooling tend to have better health and well-being and healthier behaviours. For the authors, education was an important mechanism for enhancing the health and well-being of individuals because it caused reducing the need for health care, the associated costs of dependence, lost earnings and human suffering. It also helps promote and sustain healthy lifestyles and positive choices, supporting and nurturing human development, human relationships and personal, family and community well-being.

Lleras-Muney [4] in her study searched whether education has a causal impact on health and found that for individuals born in the United States between 1914 and 1939. She reached the result that an additional year of schooling reduced the probability of dying in the next 10 years by 3.6 percentage points and had a causal impact on mortality, and that the effect was perhaps larger than has been previously estimated in the literature.

Cutler and Lleras-Muney [5] studied on the effect of education and they found that the effect of education increased with increasing years of education, with no evidence of a sheepskin effect. They also reached the result as policies that impact educational attainment could have a large effect on population health.

\footnotetext{
${ }^{1}$ According to the World Bank GDP data, 2015. http://data.worldbank.org/indicator/NY.GDP.MKTP.CD (Accesed: 19 March, 2017)

${ }^{2} 12$ periods: 1995, 2000, 2005, 2006, 2007, 2008, 2009, 2010, 2011, 2012, 2013, 2014.

${ }^{3}$ UNDP, Human Development Index (HDI), http://hdr.undp.org/en/content/human-development-index-hdi (Accesed: 19 March, 2017)
} 
In her study Spasojevic [6] investigated whether correlation between formal schooling completed with good health reflects a causal relationship between more schooling and better health. She found that for the cohort of Swedish people born between 1945 and 1955 went through two different school systems. As a result, the additional schooling generated by Sweden's compulsory school reform produced improved adult health (controlling for cohort and county effects, family background characteristics, and individual income).

Breierova and Duflo [7] used the Indonesian primary massive school construction project in the years 1973-1979 to identify the causal effect of education on fertility and mortality. They found that an increase in the average number of schooling in both female and male population reduced child mortality.

Currie and Moretti [8] estimated the effect of maternal education on birth outcomes using data from the Vital Statistics Natality files for 1970 to 1999. They found that higher maternal education improves infant health, as measured by birthweight and gestational age.

Lacheheb, Nor and Baloch [9] in their study examined the relationship between health expenditure, education and economic growth in MENA countries using panel data estimation. Their results based on random effects model estimation endorse a significant positive relationship between health expenditure, education and economic growth. Therefore, they emphasized that investment in human capital, namely health and education, will increase income in MENA countries.

In their study Başar, Künü, and Bozma [10] analysed the impacts of education and health expenditures on economic growth for Turkey. They indicated that there were many factors affecting human capital but high levels of literacy and health both had positive effects on labour force. In their study, the effects of health spending and education spending on economic growth of Turkey for the period 1998:1-2016:1 were analysed. According to the results of the study, while education spending has no significant effect on economic growth in the long-run, an increase in health spending had a positive effect.

In his study Kılıç [11] aimed to describe regional disparities in the contribution of human capital to the regional economy by comparing the years 2004 and 2011. He found that the increase in the average education level of the labour force between the years 2004 and 2011 in 7 of the 26 Nuts- 2 regions remained below the national average. In 6 of these regions, the increase in per capita added value is also below the national average. This suggests that the regions will have difficulty in getting out of the Middle Income Trap.

Analysis of education on economic growth via health improvement

Country and data selection

In the study panel data observation of 37 high income countries with 12 time periods between 1995 and 2014 and cross section data observation of same country group for the year 2014 were applied. For the analysis of Turkey, a time series data for 12 periods between 1995 and 2015 was also observed. The countries which were observed with Turkey are members of the World Bank high income grouping countries. The countries are not only high income per capita having countries but with more than one million population $^{4}$. The data was collected from the World Bank, UNDP and Barro-Lee for Turkey and 37 high income countries for 12 time periods between 1995 and 2014.

\section{Methodology}

During industrialization, basic inputs such as labour coming from rural to urban and capital accumulation that was a result of citizens' saving or other countries' investments and loans are key determinants of growth at the initial level of development for emerging countries such as Turkey. An improvement in health status of labour force increases the productivity resulting with an economic growth and enhancing income per capita in a country. Following the existing literature on the relationship between eco-

${ }^{4}$ High Income Economies have more than 12,475 USD income per capita, https://datahelpdesk.worldbank.org/knowledgebase/articles/906519-worldbank-country-and-lending-groups (Access: 26 February, 2017) 
nomic growth and education, the estimated model in the study can be described as follow:

Income per Capita, IPC, $\left\{\ln \left(\mathrm{Y}_{\mathrm{it}}\right)\right\}=f$ (Mean Years of Schooling, MYS, $\mathrm{X}_{\mathrm{it}}$ ), ln: natural logarithm

$\ln \left(Y_{i t}\right)=\alpha+\beta^{*} X_{i t}+u_{t^{\prime}} i=1,2,3 \ldots 37, t=1995-2014$ (12 periods)

Income per capita (GDP-Gross Domestic Product, per person in the country, IPC) as an indicator of economic growth and mean years of schooling as an indicator of education (MYS) were used in the study. For income per capita variables natural logarithms of the values are used.

In the study, 37 high-income countries were studied for 12 periods starting from 1995 and ending 2014. $\alpha$ is the constant coefficient (intercept) and $\beta$ is the regression coefficient (independent variable coefficient/slope). $u_{t}$ is the disturbance (error) term that represents the changes in income per capita (increase/decrease) is not defined by education at time $t$. $u_{t}$ is a random variable with well-defined probability properties and is $u_{t} \sim \operatorname{NID}^{5}\left(0, s^{2}\right)$ where $u_{t}$ has zero $(0)$ mean and common variance $\left(s^{2}\right)$ for all countries according to the Classical Normal Linear Regression and is normally and independently distributed according to time and countries [13].

Estimation and analysis of the results

The development of income (GDP) per capita during the period 1995-2014

Considering income per capita (natural logarithm) development during the period 1995-2014 in the study, Norway is the country which has got the highest income per capita among 37 High Income Countries (Figure 1). Switzerland, Australia, Denmark and Sweden are the followers of Norway in this indicator. Poland, Hungary and Crotia are the countries who have lowest income per capita. With a nearly 10.304 USD income per capita that is an amount of 3.000 USD below Crotia which has got the lowest rank among High Income Countries, Turkey is not a member of High Income Country but a member of Upper Middle Income Countries. In the figure the countries below the line where income per capita doesn't change from 1995 to 2014 mean the countries has got a progress in income per capita where the countries upper the line mean a recession in income per capita. It seems Norway has got the best performance in increasing the income per capita during the period 1995-2014 where Japan has got the worst performance with a decrease in income per capita.

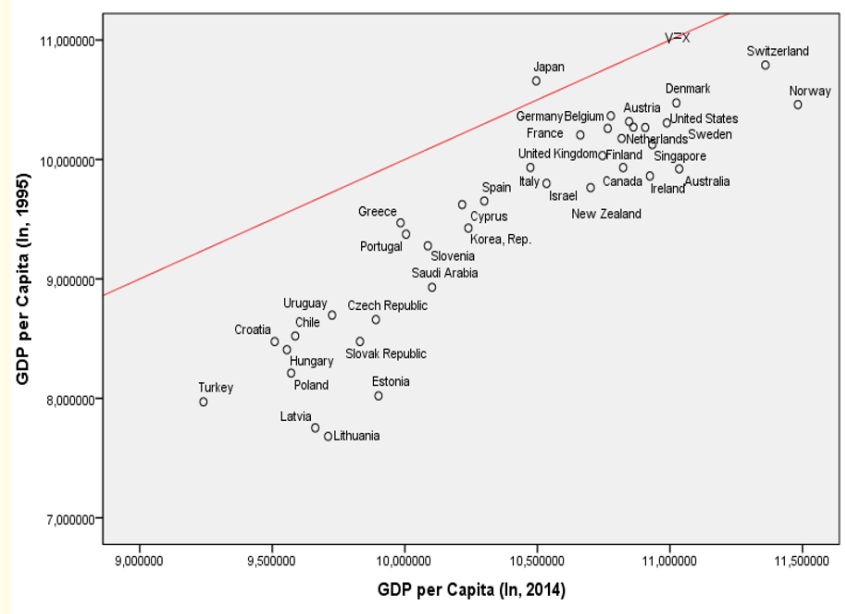

Figure 1: The Development of the Income per Capita (natural logarithm, Ln, 1995-2014).

Source: Estimated by the World Bank data.

The development of mean years of schooling during the period 1980-2014

For the period 1980-2014 only Singapore has a better positive change rate in mean years of schooling amount than Turkey among 37 high income countries. It can be obviously said that Turkey has an outstanding performance in this indicator. Singapore has got a nearly $186,5 \%$ of change rate for the period 1980-2014 ranking top where Turkey has followed her with a $162,1 \%$ change rate in the mean years of schooling. For the same period, New Zealand has been the lowest change rate in the mean years of schooling with a 7,8\% increasing rate. The countries in low human development group has a positive change rate as $200 \%$ and in very high human development group as $38,8 \%$ in the period that was mentioned above. Turkey has got a tremendous increasing education performance after 1980 but got into stuck at 7,6 average years schooling in 2012-2014 period (Table 1).

${ }^{5}$ Normally and Independently Distributed. 


\begin{tabular}{|c|c|c|c|c|c|c|c|c|c|c|}
\hline Country/Years & 1980 & 1990 & 2000 & 2006 & 2010 & 2011 & 2012 & 2013 & 2014 & Change (1980-2014) \\
\hline Singapore & 3,7 & 5,8 & 7,6 & 8,8 & 10,1 & 10,1 & 10,2 & 10,2 & 10,60 & $186,5 \%$ \\
\hline Turkey & 2,9 & 4,5 & 5,5 & 6,1 & 7,2 & 7,4 & 7,6 & 7,6 & 7,60 & $162,1 \%$ \\
\hline Germany & 5,7 & 8 & 10,5 & 12,8 & 12,9 & 12,9 & 12,9 & 12,9 & 13,10 & $129,8 \%$ \\
\hline Saudi Arabia & 4,2 & 5,5 & 7,4 & 8,2 & 8,5 & 8,5 & 8,6 & 8,7 & 8,70 & $107,1 \%$ \\
\hline Spain & 5,1 & 6,1 & 8,4 & 9,1 & 9,5 & 9,5 & 9,6 & 9,6 & 9,60 & $88,2 \%$ \\
\hline France & 6 & 7,1 & 9,8 & 10,6 & 11 & 11 & 11,1 & 11,1 & 11,10 & $85,0 \%$ \\
\hline Latvia & 6,3 & 7,5 & 9,4 & 10,6 & 11,5 & 11,5 & 11,5 & 11,5 & 11,50 & $82,5 \%$ \\
\hline Lithuania & 6,8 & 9,2 & 10,9 & 11,9 & 12,4 & 12,4 & 12,4 & 12,4 & 12,40 & $82,4 \%$ \\
\hline United Kingdom & 7,5 & 7,9 & 11,6 & 12,2 & 12,3 & 12,3 & 12,3 & 12,3 & 13,10 & $74,7 \%$ \\
\hline Cyprus & 6,7 & 8,7 & 10 & 11,9 & 11 & 11 & 11 & 11 & 11,60 & $73,1 \%$ \\
\hline Portugal & 4,8 & 6,2 & 6,6 & 7,3 & 7,8 & 8,1 & 8,2 & 8,2 & 8,20 & $70,8 \%$ \\
\hline Italy & 6,1 & 7,2 & 8,4 & 9,6 & 10,1 & 10,1 & 10,1 & 10,1 & 10,10 & $65,6 \%$ \\
\hline Korea, Rep. & 7,3 & 8,9 & 10,6 & 11,4 & 11,8 & 11,8 & 11,8 & 11,8 & 11,90 & $63,0 \%$ \\
\hline Croatia & 6,9 & 6 & 9,4 & 9,9 & 10,8 & 11 & 11 & 11 & 11,00 & $59,4 \%$ \\
\hline Greece & 6,6 & 7,9 & 8,6 & 9,9 & 10,2 & 10,2 & 10,2 & 10,2 & 10,30 & $56,1 \%$ \\
\hline Poland & 7,7 & 9,7 & 11,1 & 11,3 & 11,7 & 11,8 & 11,8 & 11,8 & 11,80 & $53,2 \%$ \\
\hline Chile & 6,4 & 8,1 & 8,8 & 9,5 & 9,8 & 9,8 & 9,8 & 9,8 & 9,80 & $53,1 \%$ \\
\hline Estonia & 8,4 & 9,3 & 11,7 & 11,9 & 12 & 12 & 12 & 12 & 12,50 & $48,8 \%$ \\
\hline Austria & 7,4 & 8,3 & 9,1 & 10,1 & 10,8 & 10,8 & 10,8 & 10,8 & 10,80 & $45,9 \%$ \\
\hline Denmark & 9 & 9,6 & 10,5 & 11,9 & 12,1 & 12,1 & 12,1 & 12,1 & 12,70 & $41,1 \%$ \\
\hline Belgium & 8,1 & 9,4 & 10 & 10,6 & 10,9 & 10,9 & 10,9 & 10,9 & 11,30 & $39,5 \%$ \\
\hline Norway & 9,1 & 10,8 & 11,5 & 12,7 & 12,6 & 12,6 & 12,6 & 12,6 & 12,60 & $38,5 \%$ \\
\hline Canada & 9,5 & 10,3 & 11,1 & 12,3 & 12,3 & 12,3 & 12,3 & 12,3 & 13,00 & $36,8 \%$ \\
\hline Uruguay & 6,3 & 7,2 & 8,1 & 8,1 & 8,3 & 8,4 & 8,5 & 8,5 & 8,50 & $34,9 \%$ \\
\hline Hungary & 8,7 & 8,7 & 10,7 & 11,2 & 11,3 & 11,3 & 11,3 & 11,3 & 11,60 & $33,3 \%$ \\
\hline Sweden & 9,1 & 10 & 11 & 11,6 & 11,7 & 11,7 & 11,7 & 11,2 & 12,10 & $33,0 \%$ \\
\hline Slovenia & 9 & 10,9 & 11,6 & 11,5 & 11,8 & 11,9 & 11,9 & 11,9 & 11,90 & $32,2 \%$ \\
\hline Japan & 8,9 & 9,9 & 10,8 & 11,2 & 11,5 & 11,5 & 11,5 & 11,5 & 11,50 & $29,2 \%$ \\
\hline Ireland & 9,5 & 10,4 & 11,2 & 11,4 & 11,6 & 11,6 & 11,6 & 11,6 & 12,20 & $28,4 \%$ \\
\hline Switzerland & 10 & 9,7 & 11,4 & 12 & 12,2 & 12,2 & 12,2 & 12,2 & 12,80 & $28,0 \%$ \\
\hline Netherlands & 9,3 & 10,2 & 10,8 & 11,8 & 11,8 & 11,8 & 11,9 & 11,9 & 11,90 & $28,0 \%$ \\
\hline Israel & 9,8 & 10,8 & 12,3 & 12,3 & 12,5 & 12,5 & 12,5 & 12,5 & 12,50 & $27,6 \%$ \\
\hline Finland & 8,3 & 8,2 & 8,2 & 10,1 & 10,3 & 10,3 & 10,3 & 10,3 & 10,30 & $24,1 \%$ \\
\hline Slovak Republic & 10,1 & 10,6 & 10,2 & 11,6 & 11,6 & 11,6 & 11,6 & 11,6 & 12,20 & $20,8 \%$ \\
\hline Czech Republic & 10,30 & 10,9 & 11,9 & 12,9 & 12 & 12 & 12 & 12 & 12,30 & $19,4 \%$ \\
\hline Australia & 11,6 & 11,7 & 11,9 & 12,2 & 12,6 & 12,7 & 12,8 & 12,8 & 13,00 & $12,1 \%$ \\
\hline United States & 11,9 & 12,3 & 12,7 & 12,8 & 12,9 & 12,9 & 12,9 & 12,9 & 12,90 & $8,4 \%$ \\
\hline New Zealand & 11,6 & 11,7 & 12 & 12,3 & 12,5 & 12,5 & 12,5 & 12,5 & 12,50 & $7,8 \%$ \\
\hline \multicolumn{11}{|l|}{ Memorandum } \\
\hline Very high human development & 8,5 & 9,5 & 10,8 & 11,4 & 11,7 & 11,7 & 11,7 & 11,7 & 11,8 & $38,8 \%$ \\
\hline
\end{tabular}




\begin{tabular}{|c|c|c|c|c|c|c|c|c|c|c|}
\hline High human development & 4,4 & 5,5 & 7,1 & 7,7 & 8,1 & 8,1 & 8,1 & 8,1 & 8,2 & $86,4 \%$ \\
\hline Medium human development & 2,5 & 3,4 & 4,5 & 5,2 & 5,5 & 5,5 & 5,5 & 5,5 & 6,2 & $148,0 \%$ \\
\hline Low human development & 1,5 & 2,3 & 3,1 & 3,8 & 4,1 & 4,2 & 4,2 & 4,2 & 4,5 & $200,0 \%$ \\
\hline
\end{tabular}

Table 1: Comparison of Mean Years of Schooling (Turkey vs High Income Countries, 1980-2014).

Source: Prepared from the United Nations Development Programme Human Development Data and Barro-Lee Educational Attainment Dataset.

http://hdr.undp.org/en/data\# (Access: 14 March 2017).

Considering education development during the period 19952014 in the study in the figure below, Germany and United Kingdom are the countries which have got the highest mean years of schooling among 37 High Income Countries in 2014. Australia, Canada, United States and Switzerland are the followers of Germany and United Kingdom in this indicator. Portugal and Uruguay are the countries who have lowest mean years of schooling value among 37 high income countries where Turkey has the lowest mean years of schooling value. With an average 7,6 schooling years that is an amount of nearly $64,4 \%$ of the very high human development country group value Turkey has got a value nearly more than $68,8 \%$ of low human development country group average value. In the figure the countries below the line where mean years of schooling doesn't change from 1995 to 2014 mean the countries has got a progress in education performance where the countries upper the line mean a recession in education performance. It seems Singapore has got the best performance in increasing the mean years of schooling during the period 1995-2014 where New Zealand has got the worst performance with a lower increase in schooling performance.

\section{Human capital}

The quality of the human capital is measured by the level of education gained during life time (mean years of schooling). Many economists such as Robert E. Lucas, Jr. [14], Robert J. Barro [12], N. Gregory Mankiw, David Romer and David N. Weil [15] interested in human capital subject. In countries who have high education-level not only an increase in labour productivity, developments in social issues such as children's education and income distribution but also a decline in child mortality and birth rates as well ${ }^{6}$.

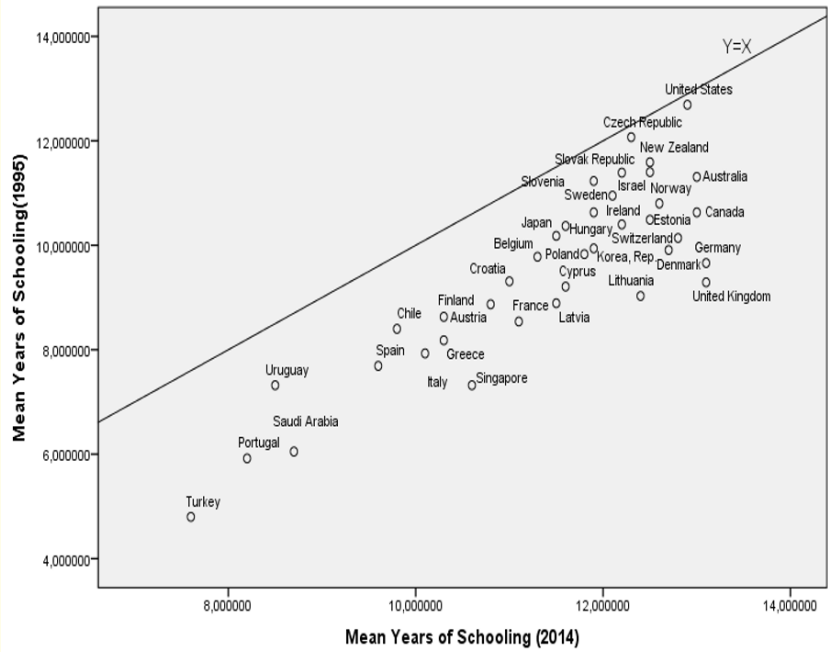

Figure 2: The Development of the Mean Years of Schooling (1995-2014).

Source: Estimated by United Nations Development Programme Human Development Reports and Barro-Lee Educational Attainment Dataset.

Barro [12] examined the relationship between national income per capita growth rate in the national economy and the human capital (mean schooling ratio) and whether the 98 countries' economies converged to each other over a period of 26 years covering the period from 1960 to 1985 . The author found that during the 26 periods, per capita income growth was positively related to human capital. In a similar study, Barro and Lee [16] investigated the effect of school enrolment levels (literacy, basic education, high school

${ }^{6}$ Barro-Lee, http://www.barrolee.com/ (Access: 23 March 2017). 
and college graduates) of over 25 years old men and women on the growth of economy growth in 129 countries and found that they were significantly positively related. They pointed out the birth rate was decreasing as the education level of women increasing.

Barro and Lee [17] examined the relationship between human capital and educational attainment in a study covering 146 countries for the period 1950-2010 and found schooling had a significantly positive effect on income.

In his study, Lucas [14] has taken into account the hope of establishing neo-classical growth and international trade theory consistent with some of the essential features of economic development. He mentioned three models in his study;

- $\quad$ The model emphasizing physical capital accumulation and technological change,

- The model emphasizing human capital accumulation through education,

- A model that emphasizes the accumulation of specialized human capital through learning by doing.

A decrease in adult mortality rate simply means an improvement in healthy population hence labour force. The adult mortality rate has a negative relationship with mean years of schooling (Figure 3). In a country, when education level increases a healthy wellbeing level is being reached where a productivity progress causing a rapid economic growth is gained.

The relationship between GDP per capita and mean years of schooling with cross-section data method

The figure which was estimated by SPSS software below shows the relationship between natural logarithm of income per capita (IPC) and mean years of schooling (MYS) for the year 2014. The positive relationship can be seen obviously between two variables with the line equation. The countries on the equation line indicates the countries where the natural logarithm of GDP per Capita and mean years of schooling are equal. The equation tells us one year increase in mean years of schooling causes approximately 0,3571 $(36 \%)$ increase in natural logarithm of GDP per capita which means nearly 11.545 USD increase in income per capita in average.

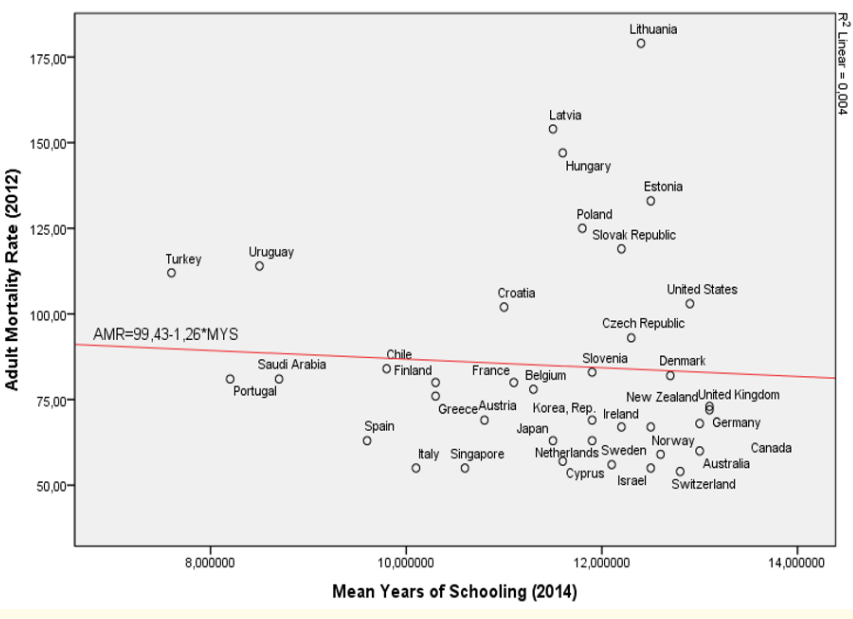

Figure 3: The Adult Mortality Ratio of Turkey and High Income Countries' Average Value (1995-2014).

Source: Estimated by the World Bank and United Nations

Development Programme Human Development Reports and Barro-Lee Educational Attainment Dataset.

In 2014, Germany and United Kingdom are the leader countries where Australia and Canada are second and United States is the fifth countries in mean years of schooling where Turkey is ranked as the country which has the lowest value. Norway is the leader in the GDP per Capita, Switzerland as the second and Australia is the third country where Crotia seems as the country which has the lowest income per capita in 37 high income countries.

If the relationship between income per capita scores (natural logarithm) and health expenditure share in national income in figure 4 is wanted be expressed as a regression ${ }^{7}$, the following equation is obtained. The equation tells us one year increase in mean schooling causes approximately 0,17 (17\%) increase in natural logarithm of GDP per Capita which means nearly 5.040 USD increase in income per capita for 37 High Income Countries in average.

$\ln \left(\mathrm{IPC}_{2014}\right)=8,47+0,17 * \mathrm{MYS}_{2014}$ ln: natural logarithm

${ }^{7}$ In the regression, 37 high income countries are observed. 


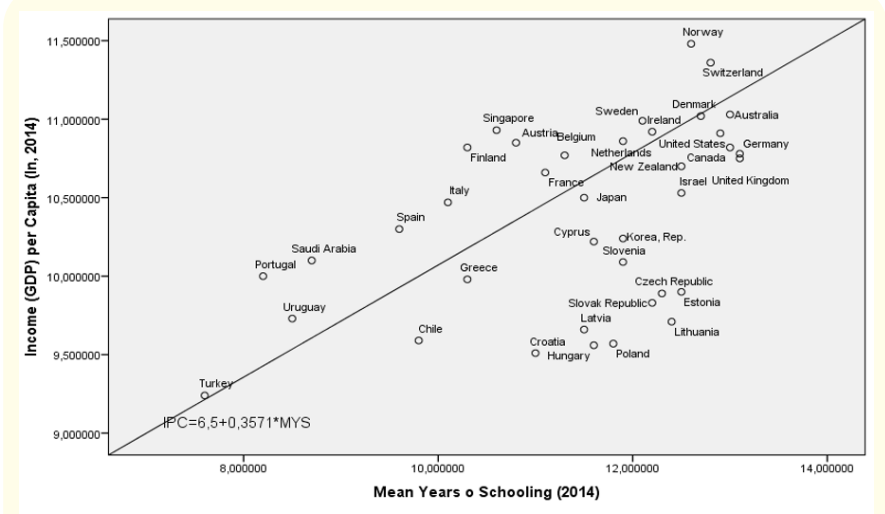

Figure 4: GDP Per Capita and Mean Years of Schooling in High Income Countries (2014).

Source: Estimated by the World Bank and United Nations Development Programme Human Development Reports and BarroLee Educational Attainment Dataset.

The cross-section data obtained by the EViews 9 software of regression results of income per capita (natural logarithm) and mean years of schooling relationship expressed by figure and regression are shown below (Table 2). In the equation approximately $16 \%$ of the changes in income per capita are expressed by mean years of schooling. The statistical values of the coefficients of the regression are statistically significant $(p<0,05$ and the absolute values of the coefficients $t$ are outside the threshold values of the t distribution).

\section{Detecting autocorrelation in the regression}

To detect the presence of autocorrelation in the residuals of the regression above the Durbin-Watson d statistic is applied.

- $\mathrm{H}_{0}$ : There is no sequential relationship between error terms (neither the same nor opposite direction)

- $\quad \mathrm{H}_{1}$ : There is a sequential relationship between error terms.

The $d$-value $\left(d_{L}\right)$ at the lower limit is taken as 1,419 and the $d$ value at the upper limit $\left(d_{U}\right)$ is taken as 1,530 with 1 explanatory variable (mean years of schooling) at level $5 \%$ and 37 observations

\begin{tabular}{|c|c|c|c|c|}
\hline & & & & \\
\hline & Depend & t Variable: L & LIPC & \\
\hline & Meth & I: Least Squa & & \\
\hline & Date: 03 & 4/17 Time: & $9: 40$ & \\
\hline & & mple: 137 & & \\
\hline & Include & observation & $: 37$ & \\
\hline Variable & Coefficient & Std. Error & t-Statistic & Prob. \\
\hline $\mathrm{C}$ & 8.469974 & 0.754217 & 11.23016 & 0.0000 \\
\hline MYS & 0.168211 & 0.065105 & 2.583701 & 0.0141 \\
\hline R-squared & 0.160178 & Mean dep & Ident var & 10.40622 \\
\hline $\begin{array}{l}\text { Adjusted } \\
\text { R-squared }\end{array}$ & 0.136183 & S.D. depe & dent var & 0.556507 \\
\hline $\begin{array}{l}\text { S.E. of } \\
\text { regression }\end{array}$ & 0.517227 & Akaike inf & criterion & 1.571869 \\
\hline $\begin{array}{c}\text { Sum } \\
\text { squared resid }\end{array}$ & 9.363333 & Schwarz & riterion & 1.658945 \\
\hline $\begin{array}{c}\text { Log } \\
\text { likelihood }\end{array}$ & -27.07957 & Hannan-Q & nn criter. & 1.602567 \\
\hline F-statistic & 6.675510 & Durbin-W & tson stat & 1.927285 \\
\hline $\begin{array}{c}\text { Prob } \\
\text { (F-statistic) }\end{array}$ & 0.014109 & & & \\
\hline
\end{tabular}

Table 2: The Relationship between GDP per Capita and Mean Years of Schooling with Cross-section Data Method.

Source: Authors' own estimation.

(country) (Gujarati and Porter, 2014: p. 888). $\mathrm{H}_{0}$ can't be rejected if $d_{U}<4-d_{U}$. As the $d(1,9273)$ value obtained in the regression is $1,530<1,9273<2,47$, the null hypothesis $\left(\mathrm{H}_{0}\right)$ can't be rejected and it can be said that there is neither the same direction nor the opposite direction sequential relationship between the error terms.

For Turkey, it can be said that income per capita has got an increasing trend after 1995 and mean years of schooling has got an increasing trend since 1960 . It can be seen that a break point emerged for income per capita in 2009 as a result of worldwide financial crisis (Figure 5).

For Turkey's time series data for 19 period $^{8}$ the regression result of income per capita (natural logarithm) and mean years of schooling is shown below.

${ }^{8} 1960,1965,1970,1975,1980,1985,1990,1995,2000$, 2005, 2006, 2007, 2008, 2009, 2010, 2011, 2012, $2013,2014$. 


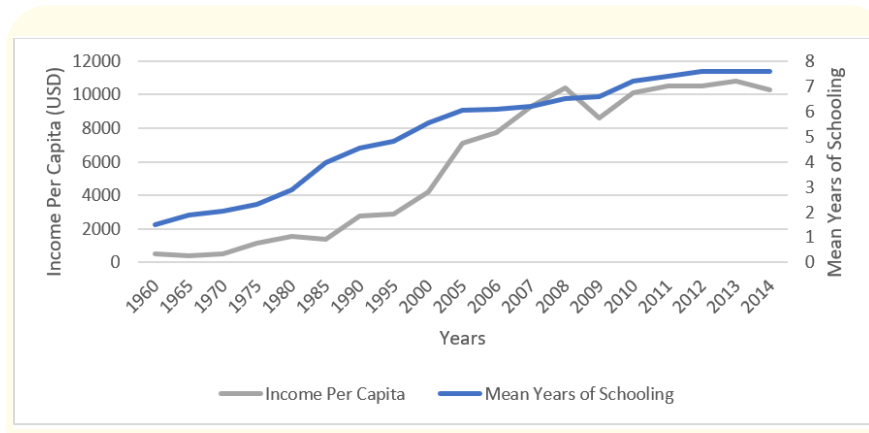

Figure 5: Turkey's Mean Years of Schooling and Income Per Capita (Annual).

Source: The World Bank, UNDP, Barro-Lee dataset.

$\ln (\mathrm{IPC})_{1960-2014}=5,42+0,54 * \mathrm{MYS}_{1960-2014}$

In the equation, nearly $95 \%$ of the changes in income per capita are expressed by mean years of schooling. The statistical values of the coefficients of the regression are statistically significant ( $p$ $<0,05$ and the absolute values of the coefficients $t$ are outside the threshold values of the $t$ distribution, Table 3).

The equation tells us one year increase in mean schooling causes approximately 0,53 (53\%) increase in natural logarithm of GDP per Capita which means nearly 4.150 USD increase in income per capita for Turkey in average.

The relationship between GDP per capita and mean years of schooling with random effect model (REM)

When the relationship between income per capita (natural logarithm) and mean years of schooling was expressed by Random Effects Model (REM) regression the following equation is obtained.

$\ln (\mathrm{IPC})_{1995-2014}=7,24+0,27^{*} \mathrm{MYS}^{9}{ }_{1995-2014}$

An increase of 1 unit in the mean years of schooling value causes an increase of about 0,27 units in the natural logarithm value of income per capita of the 37 High Income Countries which means nearly 8.420 USD increase in income per capita for 37 High Income Countries in 12 periods average.

\begin{tabular}{|c|c|c|c|c|}
\hline \multicolumn{5}{|c|}{ Dependent Variable: LN_IPC } \\
\hline \multicolumn{5}{|c|}{ Method: Least Squares } \\
\hline \multicolumn{5}{|c|}{ Date: $03 / 14 / 17$ Time: $10: 46$} \\
\hline \multicolumn{5}{|c|}{ Sample: 00010019} \\
\hline \multicolumn{5}{|c|}{ Included observations: 19} \\
\hline Variable & Coefficient & Std. Error & t-Statistic & Prob. \\
\hline $\mathrm{C}$ & 5.419293 & 0.170255 & 31.83036 & 0.0000 \\
\hline MYS & 0.537637 & 0.030514 & 17.61914 & 0.0000 \\
\hline R-squared & 0.948081 & \multicolumn{2}{|c|}{ Mean dependent var } & 8.199726 \\
\hline $\begin{array}{c}\text { Adjusted } \\
\text { R-squared }\end{array}$ & 0.945027 & \multicolumn{2}{|c|}{ S.D. dependent var } & 1.188037 \\
\hline $\begin{array}{c}\text { S.E. of } \\
\text { regression }\end{array}$ & 0.278551 & \multicolumn{2}{|c|}{ Akaike info criterion } & 0.380868 \\
\hline $\begin{array}{c}\text { Sum squared } \\
\text { resid }\end{array}$ & 1.319039 & \multicolumn{2}{|c|}{ Schwarz criterion } & 0.480283 \\
\hline Log likelihood & -1.618246 & \multicolumn{2}{|c|}{ Hannan-Quinn criter. } & 0.397693 \\
\hline F-statistic & 310.4341 & \multicolumn{2}{|c|}{ Durbin-Watson stat } & 1.248853 \\
\hline $\begin{array}{c}\text { Prob } \\
\text { (F-statistic) }\end{array}$ & 0.000000 & & & \\
\hline
\end{tabular}

Table 3: Education and Income per Capita Relationship for Turkey. Source: Authors' own estimation.

The regression of the relationship between income per capita values (natural logarithm) and mean years of schooling for the 37 High Income Countries obtained by the REM Panel Data covering the twenty years using the EViews 9 software can be seen as below.

The regression above shows that about $36 \%$ of the changes in the income per capita of the 37 High Income Countries is expressed by the mean years of schooling values of the countries. When the statistical values of the coefficients of the regression are examined; mean years of schooling coefficient (slope) and the constant coefficient are statistically significant $(\mathrm{p}<0,05$ and the absolute values of the coefficients' $t$ are outside the threshold values of the $t$ distribution). Considering the relationship between the income per capita values of the 37 High Income Countries and mean years of schooling according to the regression results obtained by using the

${ }^{9}$ The regression obtained by Pooled Ordinary Least Squares Method is as; $\ln (\mathrm{IPC}) 1995-2014=8,32+0,17 * \mathrm{MYS}_{1995-2014}$ 


\begin{tabular}{|c|c|c|c|c|}
\hline \multicolumn{5}{|c|}{ Dependent Variable: IPC } \\
\hline \multicolumn{5}{|c|}{ Method: Panel EGLS (Cross-section random effects) } \\
\hline \multicolumn{5}{|c|}{ Date: 03/08/17 Time: 14:34 } \\
\hline \multicolumn{5}{|c|}{ Sample: 112} \\
\hline \multicolumn{5}{|c|}{ Periods included: 12} \\
\hline \multicolumn{5}{|c|}{ Cross-sections included: 37} \\
\hline \multicolumn{5}{|c|}{ Total panel (balanced) observations: 444} \\
\hline \multicolumn{5}{|c|}{ Swamy and Arora estimator of component variances } \\
\hline Variable & Coefficient & Std. Error & t-Statistic & Prob. \\
\hline $\mathrm{C}$ & 7.238239 & 0.208848 & 34.65791 & 0.0000 \\
\hline \multirow[t]{3}{*}{ MYS } & 0.267062 & 0.016770 & 15.92474 & 0.0000 \\
\hline & \multicolumn{4}{|c|}{ Effects Specification } \\
\hline & & & S.D. & Rho \\
\hline \multicolumn{3}{|c|}{ Cross-section random } & 0.595700 & 0.8201 \\
\hline \multicolumn{3}{|c|}{ Idiosyncratic random } & 0.278964 & 0.1799 \\
\hline & \multicolumn{4}{|c|}{ Weighted Statistics } \\
\hline R-squared & 0.363342 & \multicolumn{2}{|c|}{ Mean dependent var } & 1.362200 \\
\hline $\begin{array}{l}\text { Adjusted } \\
\text { R-squared }\end{array}$ & 0.361902 & \multicolumn{2}{|c|}{ S.D. dependent var } & 0.350155 \\
\hline $\begin{array}{c}\text { S.E. of } \\
\text { regression }\end{array}$ & 0.279707 & \multicolumn{2}{|c|}{ Sum squared resid } & 34.58043 \\
\hline F-statistic & 252.2503 & \multicolumn{2}{|c|}{ Durbin-Watson stat } & 0.613015 \\
\hline \multirow{2}{*}{$\begin{array}{c}\text { Prob } \\
\text { (F-statistic) }\end{array}$} & 0.000000 & & & \\
\hline & \multicolumn{4}{|c|}{ Unweighted Statistics } \\
\hline R-squared & 0.088156 & \multicolumn{2}{|c|}{ Mean dependent var } & 10.16820 \\
\hline $\begin{array}{l}\text { Sum squared } \\
\text { resid }\end{array}$ & 197.2279 & \multicolumn{2}{|c|}{ Durbin-Watson stat } & 0.107481 \\
\hline
\end{tabular}

Table 4: The Relationship between GDP per Capita and Mean Years of Schooling with Random Effect Model (REM).

Source: Authors' own estimation.

Cross-sectional Data Method is also confirmed by the regression results obtained using the Panel Data Method.

To test the validity of the Random Effects Model, which shows the relationship between mean years of schooling and income per capita (natural logarithm) obtained with the EViews 9 software above, with the Hausman Test:
- $\mathrm{H}_{0}$ : Random Effects Model (REM) can be applied,

- $\quad \mathrm{H}_{1}$ : Fixed Effects Model (SEM) can be applied.

The following Hausman test also shows that null hypothesis indicating Random Effects Model (REM) can be applied can't be

\begin{tabular}{|c|c|c|c|c|}
\hline \multicolumn{5}{|c|}{ Correlated Random Effects - Hausman Test } \\
\hline \multicolumn{5}{|c|}{ Equation: Untitled } \\
\hline \multicolumn{5}{|c|}{ Test cross-section random effects } \\
\hline \multicolumn{2}{|c|}{ Test Summary } & $\begin{array}{l}\text { Chi-Sq. } \\
\text { Statistic }\end{array}$ & Chi-Sq. d.f. & Prob. \\
\hline \multicolumn{2}{|c|}{ Cross-section random } & 3.360603 & 1 & 0.0668 \\
\hline \multicolumn{5}{|c|}{ Cross-section random effects test comparisons: } \\
\hline Variable & Fixed & Random & Var (Diff.) & Prob. \\
\hline MYS & 0.274052 & 0.267062 & 0.000015 & 0.0668 \\
\hline \multicolumn{5}{|c|}{ Cross-section random effects test equation } \\
\hline \multicolumn{5}{|c|}{ Dependent Variable: IPC } \\
\hline \multicolumn{5}{|c|}{ Method: Panel Least Squares } \\
\hline \multicolumn{5}{|c|}{ Date: 03/08/17 Time: 14:34 } \\
\hline \multicolumn{5}{|c|}{ Sample: 112} \\
\hline \multicolumn{5}{|c|}{ Periods included: 12} \\
\hline \multicolumn{5}{|c|}{ Cross-sections included: 37} \\
\hline \multicolumn{5}{|c|}{ Total panel (balanced) observations: 444} \\
\hline Variable & Coefficient & Std. Error & t-Statistic & Prob. \\
\hline $\mathrm{C}$ & 7.161549 & 0.189148 & 37.86220 & 0.0000 \\
\hline \multirow[t]{2}{*}{ MYS } & 0.274052 & 0.017198 & 15.93485 & 0.0000 \\
\hline & \multicolumn{3}{|c|}{ Effects Specification } & \\
\hline \multicolumn{5}{|c|}{ Cross-section fixed (dummy variables) } \\
\hline R-squared & 0.853926 & \multicolumn{2}{|c|}{ Mean dependent var } & 10.16820 \\
\hline $\begin{array}{c}\text { Adjusted } \\
\text { R-squared }\end{array}$ & 0.840614 & \multicolumn{2}{|c|}{ S.D. dependent var } & 0.698751 \\
\hline $\begin{array}{l}\text { S.E. of } \\
\text { regression }\end{array}$ & 0.278964 & \multicolumn{2}{|c|}{ Akaike info criterion } & 0.366228 \\
\hline $\begin{array}{l}\text { Sum squared } \\
\text { resid }\end{array}$ & 31.59518 & \multicolumn{2}{|c|}{ Schwarz criterion } & 0.716772 \\
\hline Log likelihood & -43.30267 & \multicolumn{2}{|c|}{ Hannan-Quinn criter. } & 0.504467 \\
\hline F-statistic & 64.14632 & \multicolumn{2}{|c|}{ Durbin-Watson stat } & 0.683258 \\
\hline $\begin{array}{c}\text { Prob } \\
\text { (F-statistic) }\end{array}$ & 0.000000 & & & \\
\hline
\end{tabular}

Table 5: Hausman Test.

Source: Authors' own estimation. 
rejected, since with $1 \mathrm{df}$ (degree of freedom) and $X^{2}$ (chi-square) value is not statistically significant.

If the null hypothesis is rejected, the alternative one which tells us Fixed Effects Model (SEM) can be applied for the relationship should be accepted and the regression estimated by Fixed Effect Model should be as below.

$$
\ln (\mathrm{IPC})_{1995-2014}=7,16+0,27 * \mathrm{MYS}_{1995-2014}
$$

\section{Granger causality tests}

The Granger Causality tests may be approved for both panel and cross-section data set to show the direction of the causality between mean years of schooling and economic growth (income per capita increase) and vice versa.

To test mean years of schooling (MYS) causes economic growth (IPC)?

$\ln (\text { IPC })_{i t}=a_{i}+b_{i} * \ln (\text { MYS })_{i t}+u_{i t}$

- $\mathrm{H}_{0}$ : Mean years of schooling (MYS) does not Granger cause economic growth (IPC)

- $\quad \mathrm{H}_{1}$ : Mean years of schooling (MYS) Granger causes economic growth (IPC)

To test economic growth (IPC) causes mean years of schooling (MYS)?

$\ln (\text { MYS })_{\text {it }}=a_{i}+b_{i} * \ln (\text { IPC })_{i t}+w_{i t}$

- $\mathrm{H}_{0}$ : Economic growth (IPC) does not Granger cause mean years of schooling (MYS)

- $\mathrm{H}_{1}$ : Economic growth (IPC) Granger causes mean years of schooling (MYS).

$\mathrm{i}=1,2,3 \ldots 37, \mathrm{t}=1995-2014$ (12 periods) for panel data and $\mathrm{t}$ $=2014$ for cross-section data and the disturbances $\mathrm{u}_{\mathrm{it}}$ and $\mathrm{w}_{\mathrm{it}}$ are uncorrelated.

\begin{tabular}{|c|c|c|c|}
\hline \multicolumn{4}{|c|}{ Pairwise Granger Causality Tests } \\
\hline \multicolumn{4}{|c|}{ Date: 10/02/17 Time: 16:21 } \\
\hline \multicolumn{4}{|l|}{ Sample: 112} \\
\hline \multicolumn{4}{|l|}{ Lags: 2} \\
\hline Null Hypothesis & Obs & $\begin{array}{c}\text { F-Statis- } \\
\text { tic }\end{array}$ & Prob. \\
\hline MYS does not Granger Cause LN_IPC & 370 & 7.17787 & 0.0009 \\
\hline \multicolumn{2}{|l|}{ LN_IPC does not Granger Cause MSY } & 0.75148 & 0.4724 \\
\hline
\end{tabular}

Table 6: Pairwise Granger Causality Tests with Panel Data.

Source: Authors' own estimation.

According to the Table 6 results computed, $\mathrm{F}$ value exceeds the critical $F$ value and $p<0,05$ level of significance, so we reject null hypotheses and accept that mean years of schooling (MYS) Granger causes economic (income per capita) growth (IPC) for panel data model.

\begin{tabular}{|c|c|c|c|}
\hline \multicolumn{4}{|c|}{ Pairwise Granger Causality Tests } \\
\hline \multicolumn{4}{|c|}{ Date: 10/02/17 Time: 16:16 } \\
\hline \multicolumn{4}{|l|}{ Sample: 137} \\
\hline \multicolumn{4}{|l|}{ Lags: 2} \\
\hline Null Hypothesis & Obs & $\begin{array}{c}\text { F-Statis- } \\
\text { tic }\end{array}$ & Prob. \\
\hline MYS does not Granger Cause LN_IPC & 35 & 0.58290 & 0.5645 \\
\hline \multicolumn{2}{|l|}{ LN_IPC does not Granger Cause MYS } & 1.08997 & 0.3492 \\
\hline
\end{tabular}

Table 7: Pairwise Granger Causality Tests with Cross-section Data.

Source: Authors' own estimation.

According to the table 7 results computed $\mathrm{F}$ values do not exceed the critical $F$ value and $p>0,05$ level of significance so we are not able to reject both null hypotheses which imply that mean years of schooling Granger does not cause economic growth (IPC) and vice versa for cross-section model. 


\section{Conclusion}

Even the mean years of schooling has got a progressive increasing during the 12 periods between 1995-2014 education level is still below High Income Countries. Comparing with advanced countries Turkey should increase mean years of schooling to reach an economic growth improving productivity resulting with a healthy labour force.

Analysis of the results of Cross Section Model estimation shows that the equation: $\ln \left(\mathrm{IPC}_{2014}\right)=8,47+0,17 * \mathrm{MYS}_{2014} \ln$ : natural logarithm, tells us one percent increase in mean years of schooling causes approximately 0,17 (17\%) increase in natural logarithm of GDP per Capita which means nearly 5.040 USD increase in income per capita for 37 High Income Countries in average. In the equation about $16 \%$ of the changes in income per capita are expressed by mean years of schooling.

When the relationship between income per capita (natural logarithm) and health expenditure share in national income was expressed by REM regression the equation is, $\ln (\text { IPC })_{1995-2014}=7,24$ $+0,27^{*} \mathrm{MYS}^{10}{ }_{1995-2014}$ is estimated. An increase of 1 unit in mean years of schooling value causes an increase of about 0,27 (27\%) units in the natural logarithm value of income per capita of the 37 High Income Countries which means nearly 8.420 USD increase in income per capita for 37 High Income Countries in 12 years period average.

The regression of the relationship between income per capita values (natural logarithm) and education level for the 37 High Income Countries obtained by the Random Effect Model Panel Data covering the 12 years obtained using the EViews 9 software shows that nearly $36 \%$ of the changes in the income per capita of the 37 High Income Countries is expressed by mean years of schooling values of the countries.

For Turkey, the regression tells us one year increase in mean schooling causes approximately 0,53 (53\%) increase in natural logarithm of GDP per Capita which means nearly 4.150 USD in- crease in income per capita for Turkey 19 in average. It was estimated that nearly $95 \%$ of the changes in the income per capita of Turkey is expressed by mean years of schooling values of the countries.

According to the Granger causality test the direction of causality between mean years of schooling and income per capita of a country test, it is seen that mean years of schooling (MYS) Granger causes for economic growth (IPC) for panel data. For cross-section data analysis there is no proved correlation between mean years of schooling (MYS) and economic growth (IPC) and vice versa.

\section{Bibliography}

1. Barro R and J W Lee. "A New Data Set of Educational Attainment in the World, 1950-2010". Journal of Development Economics 104 (2013): 184-198.

2. UNDP. Human Development Report. "Work for Human Development" (2015).

3. Feinstein L., et al. "Measuring the Effects of Education on Health and Civic Engagement". Proceedings of the Copenhagen Symposium (2006): 171-354.

4. Lleras-Muney A. "The Relationship between Education and Adult Mortality in the United States". Review of Economic Studies 72 (2005): 189-221.

5. Cutler DM and A Lleras-Muney. "Education and Health: Evaluating Theories and Evidence". NBER Working Paper No. (2005): 12352.

6. Spasojevic J. "Effects of Education on Adult Health in Sweden: Results from a Natural Experiment". in Daniel Slottje, Rusty Tchernis (ed.) Current Issues in Health Economics (Contributions to Economic Analysis, Volume 290) Emerald Group Publishing Limited (2010): 179-199.

\footnotetext{
${ }^{10}$ The Regression obtained by Pooled Ordinary Least Squares Method is as; Ln (IPC) $)_{1995-2014}=8,47+0,18 * \mathrm{HEXP}_{1995-2014}$
} 
7. Breierova L and E Duflo. "The Impact of Education on Fertility and Child Mortality: Do Father's Really Matter Less Than Mothers?". National Bureau of Economic Research (NBER) (2002).

8. Currie J and E Moretti. "Mother's Education and the Intergenerational Transmission of Human Capital: Evidence from College Openings and Longitudinal Data". Working Paper 9360 NBER (2017).

9. Lacheheb M., et al. "Health Expenditure, Education, and Economic Growth in Mena Countries". MPRA Paper No. (2014): 60388.

10. Basar S., et al. "Impacts of Education and Health Expenditures on Economic Growth: An Application on Turkey". Journal of Social Science, Igdir University 10 (2016): 189-204.

11. Kılıç Y. "The Relationship between Economic Growth and Education: Regional Differences in Turkey". Amme Idaresi Dergisi 48.2 (2015): 129-156.

12. Barro R. "Economic Growth in a Cross Section of Countries". The Quarterly Journal of Economics 106.2 (1991): 407-443.

13. Gujarati D N and Porter DC. Basic Econometrics. McGraw-Hill/ Irwin, 5th edition (2009).

14. Lucas R E Jr. "On the Mechanics of Economic Development". Journal of Monetary Economics 22.1 (1988): 3-42.

15. Mankiw N G., et al. "A Contribution to the Empirics of Economic Growth". The Quarterly Journal of Economics 107.2 (1992): 407-437.

16. Barro R J and J W Lee. "International Comparisons of Educational Attainment". National Bureau of Economic Research Working Paper Series (1993): 4349.

17. Barro R J and J W Lee. "A New Data Set of Educational Attainment in the World, 1950-2010". NBER Working Paper. National Bureau of Economic Research Working Paper Series (2010): 15902.

\section{Assets from publication with us}

- Prompt Acknowledgement after receiving the article

- Thorough Double blinded peer review

- Rapid Publication

- Issue of Publication Certificate

- High visibility of your Published work

Website: www.actascientific.com/

Submit Article: www.actascientific.com/submission.php

Email us: editor@actascientific.com

Contact us: +919182824667 